\title{
Regionally extinct species rediscovered: the bush dog Speothos venaticus in Minas Gerais, south-eastern Brazil
}

\author{
Guilherme Braga Ferreira, Marcelo Juliano Rabelo Oliveira \\ Rogério Cunha de Paula, Flávio Henrique Guimarães Rodrigues \\ and Érica Daniele Cunha Carmo
}

\begin{abstract}
The bush dog Speothos venaticus, a rare Near Threatened South American canid that lives in packs, was thought to be extinct in Minas Gerais state, south-eastern Brazil, until recently. Here, we report four recent records of the species in Minas Gerais, the first in the state since the description of the species in 1842 . All records are from the Cerrado ecosystem in the north and north-west of the state; two are from animals found dead, one from footprints and another from a camera trap. Three of the records were inside or close $(<10 \mathrm{~km})$ to strict protected areas, in a region recognized as the Protected Areas Mosaic Sertão VeredasPeruaçu, where we expect any new records of the bush dog to be found. We discuss the low probability of detecting the bush dog and the main regional threats to the species, and emphasize the need to protect large and interconnected natural areas and keep them free of domestic dogs to avoid the extinction of the bush dog in Minas Gerais.
\end{abstract}

Keywords Brazil, bush dog, Cerrado, Minas Gerais, regional extinction, Speothos venaticus

$\mathrm{T}$ he bush dog Speothos venaticus is the most social I of small canids (Eisenberg \& Redford, 1999) and can hunt relatively large prey such as caviomorph rodents (Zuercher et al., 2005) and armadillos, especially Dasypus novemcinctus (Lima et al., 2009). Few aspects of its ecology and behaviour in the wild are known, and before the studies by Zuercher et al. (2005) and Lima et al. $(2009,2012)$ most of the information about the species came from occasional encounters (e.g. Silveira et al., 1998) and observations in captivity (e.g. Macdonald, 1996). The bush dog is

Guilherme Braga Ferreira (Corresponding author) and Marcelo Juliano RaBelo Oliveira Instituto Biotrópicos, Januária, Minas Gerais, Brazil E-mail guilherme@biotropicos.org.br

Rogério Cunha DE Paula Instituto Chico Mendes de Conservação da Biodiversidade, Centro Nacional de Pesquisas para a Conservação de Predadores Naturais, Atibaia, São Paulo, Brazil

Flávio Henrique Guimarães Rodrigues Departamento de Biologia Geral, Universidade Federal de Minas Gerais, Belo Horizonte, Minas Gerais, Brazil

Érica Daniele Cunha Carmo Sustentar Meio Ambiente, Consultoria ambiental, Contagem, Minas Gerais, Brazil

Received 9 July 2013. Revision requested 9 September 2013.

Accepted 29 January 2014. First published online 1 August 2014. categorized as Near Threatened globally (DeMatteo et al., 2011) and as Vulnerable in Brazil (Machado et al., 2008). S. venaticus was previously considered extinct in Minas Gerais state (Costa, 1998) and, although it is currently categorized regionally as Critically Endangered (Chiarello et al., 2008), the rediscovery of the species has not been properly documented.

The state of Minas Gerais in south-eastern Brazil harbours three major ecosystems: Atlantic Forest, Caatinga and Cerrado. Caatinga is a mosaic of thorn scrub and seasonally dry forests associated with a semi-arid climate, and Cerrado is a savannah formed of several vegetation physiognomies. Here we describe four recent records of $S$. venaticus in Minas Gerais state (Table 1, Fig. 1), the first there since the species was first described (Lund, 1842).

In 2003 we found bush dog footprints in Cavernas do Peruaçu National Park, northern Minas Gerais, in the transition zone between Cerrado and Caatinga. Despite our considerable camera trap efforts (c. 7,000 trap-days at 30 sites) the species was never recorded again in this Park. In March 2011 a bush dog carcass was found in an extensive cattle ranch in northern Minas Gerais, after a local resident reported that three of his domestic dogs attacked two bush dogs and killed one of them. The site is within Cochá Gibão Environmental Protection Area (IUCN category V) and c. $8 \mathrm{~km}$ from the $70-\mathrm{km}^{2}$ Porto Cajueiro Private Reserve. In May 2012 a bush dog was found run over on the paved road BR-251, in the municipality of Unaí, in the north-west of the state. The site is not close to any protected area. In September 2012, at Veredas do Peruaçu State Park, we obtained the first camera-trap image of $S$. venaticus in Minas Gerais. Sightings of bush dogs had been reported by staff of this Park since 2004 but the species was recorded only 7 years after our first attempt to confirm its occurrence (in c. 6,000 camera-trap days at 70 sites).

All these records are from the north and north-west of Minas Gerais, where relatively large areas of Cerrado and dry forest remnants still occur, and from where we expect any new records of the bush dog to be found. Three of the four records were either inside or close to strict protected areas (IUCN categories I-IV), in a region officially recognized as the Protected Areas Mosaic Sertão VeredasPeruaçu, which is one of the most important areas for long-term conservation in south-east Brazil, extending over 
TABLE 1 Details of the four recent records of the bush dog Speothos venaticus in Minas Gerais state, south-eastern Brazil (the record numbers correspond to the numbered locations in Fig. 1).

\begin{tabular}{|c|c|c|c|c|c|}
\hline Record & Year & Site name & Site characteristics & Record type & Age \& sex \\
\hline 1 & 2003 & $\begin{array}{l}\text { Cavernas do Peruaçu } \\
\text { National Park } \\
\left(568 \mathrm{~km}^{2}\right)\end{array}$ & $\begin{array}{l}\text { Well preserved gallery forest } \\
\text { \& dry forest along the Peruaçu } \\
\text { river, near large karstic caves. }\end{array}$ & Footprints & Unidentified \\
\hline 2 & 2011 & $\begin{array}{l}\text { Lagoa da Pedra Farm, } \\
\text { Januária municipality }\end{array}$ & $\begin{array}{l}\text { Grasslands, secondary cerrado }{ }^{1} \\
\& \text { veredas }{ }^{2} \text { with extensive } \\
\text { cattle ranching }\end{array}$ & $\begin{array}{l}\text { Carcass deposited at UFMG } \\
\text { Zoology Department } \\
\text { (UFMG 3781) }\end{array}$ & Adult, unidentified sex \\
\hline 3 & 2012 & $\begin{array}{l}\text { Federal road BR-251, } \\
\text { Unaí municipality }\end{array}$ & $\begin{array}{l}\text { Paved road characterized by } \\
\text { cerradão }{ }^{4} \& \text { dry forests } \\
\text { on its margins, surrounded by } \\
\text { large agricultural lands }\end{array}$ & $\begin{array}{l}\text { Carcass deposited at PUC-MG } \\
\text { Natural Science Museum } \\
(\mathrm{MCN}-\mathrm{M} 2795)\end{array}$ & Adult male \\
\hline 4 & 2012 & $\begin{array}{l}\text { Veredas do Peruaçu } \\
\text { State Park }\left(310 \mathrm{~km}^{2}\right)\end{array}$ & $\begin{array}{l}\text { Secondary cerrado in an area } \\
\text { used for Eucalyptus plantation } \\
25 \text { years ago }\end{array}$ & Camera-trap video & Adult, unidentified sex \\
\hline
\end{tabular}

${ }^{1}$ Typical Cerrado ecosystem physiognomy, sparse trees and large shrubs $2-8 \mathrm{~m}$ tall with a grass ground layer

${ }^{2}$ Humid grassland vegetation dominated by the palm Mauritia flexuosa

${ }^{3}$ Universidade Federal de Minas Gerais

${ }^{4}$ Tall Cerrado vegetation with large trees

${ }^{5}$ Pontifícia Universidade Católica de Minas Gerais

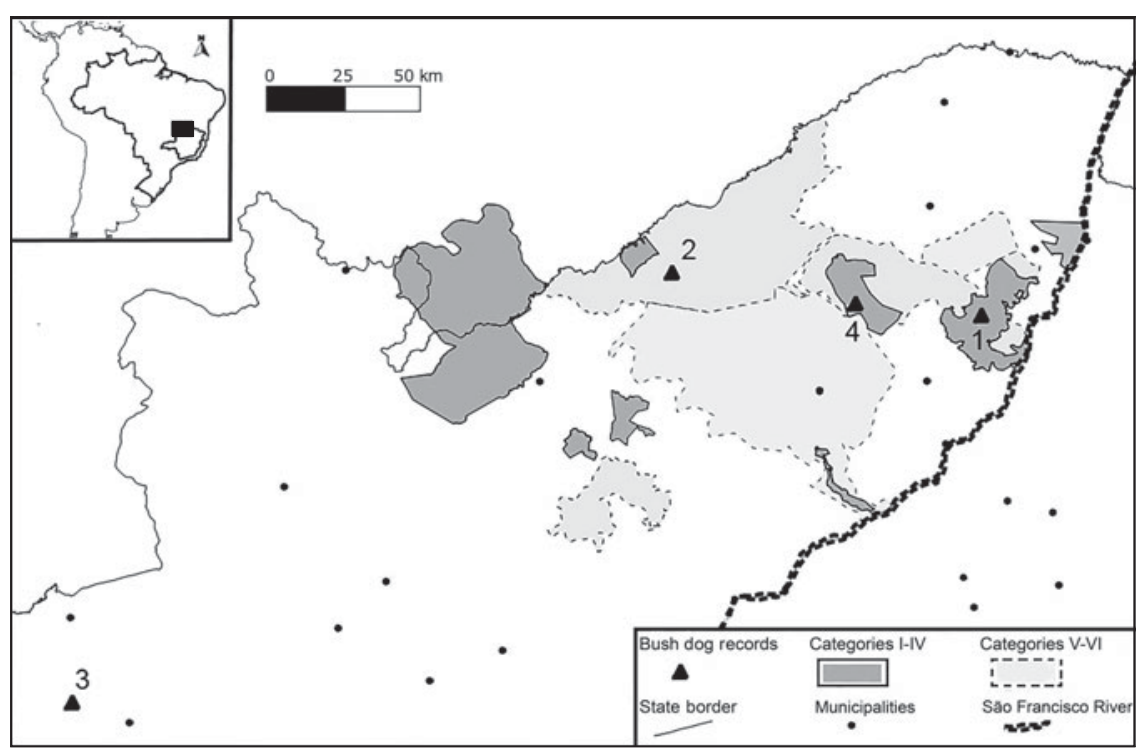

FIG. 1 Location of the four recent records of the bush dog Speothos venaticus (Table 1) in the state of Minas Gerais, south-east Brazil. Only protected areas within the Protected Areas Mosaic Sertão Veredas-Peruaçu are shown. Categories refer to the IUCN protected area categories (Dudley, 2008). The filled rectangle on the inset indicates the location of the main map in Brazil.
$18,000 \mathrm{~km}^{2}$ and largely covered with natural habitats. The Peruaçu River watershed, where two of the records were obtained and where the species is often reported by local people, appears to be an important area for conservation and studies of the bush dog in south-east Brazil.

We have been studying large mammals in the Protected Areas Mosaic Sertão Veredas-Peruaçu since 2004. These studies used techniques suitable for recording bush dogs, such as searching for tracks, track plots and camera trapping (totalling c. 27,00o trap-days). Despite this effort, S. venaticus was recorded only on three occasions. Similarly, Beisegel (2009) and Fusco-Costa \& Ingberman (2013) reported that the bush dog was recorded in the Atlantic Forest only after 4,800 and 4,112 trap-days, respectively.
In the Brazilian Amazon, Michalski (2010) obtained an average of one camera trap record for each 3,361 days of sampling. In Emas National Park, central Brazil, bush dogs were seen only nine times in 33 years (Silveira et al., 1998). These facts indicate that the bush dog has an extremely low probability of detection (which may result in false absences), probably caused by the synergistic effect of the species' large home range and its use of armadillo burrows as rest sites (Lima et al., 2012), in conjunction with small population sizes and low density. There is a need to improve techniques to detect S. venaticus. Playback vocalizations (DeMatteo et al., 2004) combined with camera trapping can provide insights about pack size, and detection dogs can be useful to find scats and dens (DeMatteo et al., 2009; Lima et al., 2009). 
The two carcasses were found in disturbed environments. Although S. venaticus can occur in such areas (Oliveira, 2009) these are not optimal habitat for the species, and mortality may be high. Lima et al. (2012) observed that bush dogs prefer natural habitats, avoiding cultivated lands even in a highly fragmented area.

As $S$. venaticus is exclusively carnivorous (Zuercher et al., 2005; Lima et al., 2009, 2012) its occurrence is conditional on the presence of prey. The species' main prey occur in the protected areas in the Protected Areas Mosaic Sertão Veredas-Peruaçu (Fundação Pró-Natureza, 2003; Ferreira et al., 2011). Some of these protected areas may support large prey populations and thus prey depletion is probably not a major threat to bush dogs in the region. The main threats in the short- and medium-term may be related to contact with domestic dogs and loss of habitat. Domestic dogs can kill bush dogs, and may transmit diseases (Jorge et al., 2010). Measures are required to eradicate domestic dogs from areas managed strictly for conservation. In protected areas where human populations are allowed, domestic dogs must be kept free of disease and close to human settlements. Loss of habitat, particularly outside protected areas, may restrict movement of individuals between packs or populations. Currently the protected areas in northern Minas Gerais are connected to some extent, but any further conversion of Cerrado into farmland could result in the isolation of these reserves. Although knowledge about bush dogs in the wild is still to be acquired, addressing the threats detailed here is crucial to safeguard the species in the state of Minas Gerais.

\section{Acknowledgement}

We thank the Conservation Leadership Programme, CENAP/ICMBio, IDESE/Usina Coruripe, IEF-MG, Panthera, Idea Wild and WWF-Brasil for funding projects that provided some of the data. Some of the authors were conducting an assessment for Geoclock and Spelayon Consultoria when some of the records were obtained. IEF-MG and ICMBio provided support during field work. Apolonio Junior prepared Fig. 1 and Luiz Otávio de Oliveira Ferreira revised the English.

\section{References}

Beisegel, B.M. (2009) First camera trap records of bush dog in the state of São Paulo, Brazil. Canid News, 12.5. Http://www.canids.org/ canidnews/12/Bush_dogs_in_Sao_Paulo.pdf [accessed 25 June 2014].

Chiarello, A.G., Aguiar, L.M.S., Gregorin, R., Hirsch, A., Melo, F.R., Paglia, A.P. \& Rodrigues, F.H.G. (2008) Mamíferos Ameaçados de Extinção em Minas Gerais. In Listas vermelhas das espécies da fauna e da flora ameaçadas de extinção em Minas Gerais (eds G.M. Drummond, A.B.M. Machado, C.S. Martins, M.P. Mendonça \& J.R. Stehmann). Fundação Biodiversitas, Belo Horizonte, Brazil.
Costa, C.M.R. (1998) Speothos venaticus. In Livro vermelho das espécies ameaçadas de extinção da fauna de Minas Gerais (eds A.B.M. Machado, G.A.B. Fonseca, R.B. Machado, L.M.S. Aguiar \& L.V. Lins), pp. 105-107. Fundação Biodiversitas, Belo Horizonte, Brazil.

DeMatteo, K.E., Carrillo, O., Zuercher, G.L., Ramírez, S. Smith, K. \& Porton, I.J. (2004) A technique for attracting bush dogs (Speothos venaticus) in the wild. Canid News, 7.6. Http://www. canids.org/canidnews/7/Attracting_bush_dogs.pdf [accessed 25 June 2014].

DeMatteo, K.E., Michalski, F. \& Leite-Pitman, M.R.P. (2011) Speothos venaticus. In IUCN Red List of Threatened Species v. 2014.1. Http://www.iucnredlist.org [accessed 25 June 2014].

DeMatteo, K.E., Rinas, M.A., Sede, M.M, Davenport, B, Arguelles, C.F., Lovett, K. \& PArker, P.G. (2009) Detection dogs: an effective technique for bush dog surveys. Journal of Wildlife Management, 73, 1436-1440.

Dudley, N. (2008) Guidelines for Applying Protected Area Management Categories. IUCN, Gland, Switzerland.

EisenberG, J.F. \& Redford, K.H. (1999) Mammals of the Neotropics, vol. 3. Chicago University Press, Chicago, USA.

Ferreira, G.B., Oliveira, M.J.R.O., Moraes, Jr, E.A., Silva, J.A. \& Rodrigues, F.H.G. (2011) Mamíferos de médio e grande porte do Parque Estadual Veredas do Peruaçu: riqueza, composição e estratégias de conservação. $M G$-Biota, 4 , 6-19.

Fundação Pró-Natureza (2003) Plano de Manejo do Parque Nacional Grande Sertão Veredas. Ministério do Meio Ambiente/ Funatura, Brasília, Brazil.

Fusco-Costa, R. \& Ingberman, B. (2013) Records of bush dog Speothos venaticus in a continuous remnant of coastal Atlantic Forest in southern Brazil. Oryx, 47, 105-108.

Jorge, R.S.P., Pereira, M.S., Morato, R.G., Scheffer, K.C., Carnieli, Jr, P., Ferreira, F. et al. (2010) Detection of rabies virus antibodies in Brazilian free-ranging wild carnivores. Journal of Wildlife Diseases, 46, 1310-1315.

Lima, E.S., DeMatteo, K.E., Jorge, R.S.P., Jorge, M.L.S.P., Lima, H.S., Dalponte, J. C. \& Klorfine, S.A. (2012) First telemetry study of bush dogs: home range, activity and habitat selection. Wildlife Research, 39, 512-519.

Lima, E.S., Jorge, R.S.P. \& DalPonte, J.C. (2009) Habitat use and diet of bush dogs, Speothos venaticus, in the Northern Pantanal, Mato Grosso, Brazil. Mammalia, 73, 13-19.

Lund, P.W. (1842) Blik paa Brasiliens Dyreverden för Sidste Jordomvaeltning. Det Kongelige Danske Videnskabernes Selskbas Naturvidenskabelige og Mathematiske Afhandlinger, 9, 137-208.

Macdonald, D.W. (1996) Social behaviour of captive bush dogs (Speothos venaticus). Journal of Zoology, 239, 525-543.

Machado, A.B.M., Drummond, G.M. \& Paglia, A.P. (2008) Livro vermelho da fauna brasileira ameaçada de extinção. Ministério do Meio Ambiente, Brasília, Brazil.

Michalski, F. (2010) The bush dog Speothos venaticus and short-eared dog Atelocynus microtis in a fragmented landscape in southern Amazonia. Oryx, 44, 300-303.

Oliveira, T.G. (2009) Distribution, habitat utilization and conservation of the vulnerable bush dog Speothos venaticus in northern Brazil. Oryx, 43, 247-253.

Silveira, L., Jácomo, A.T.A., Rodrigues, F.H.G. \& Diniz-Filho, J.A.F. (1998) Bush dogs (Speothos venaticus) in Emas National Park, Brazil. Mammalia, 62, 446-449.

Zuercher, G.L., Gipson, P.S. \& Carrillo, O. (2005) Diet and habitat association of bush dogs (Speothos venaticus) in the interior Atlantic Forest of eastern Paraguay. Oryx, 39, 86-89. 


\section{Biographical sketches}

GUilherme FerReira is currently evaluating the factors influencing the large mammal community in protected areas of northern Minas Gerais, where he has been conducting research since 2004. Marcelo Oliveira has been developing research on large mammals in the Cerrado and Atlantic Forest for the last 6 years. RogéRIO DE PAULA is responsible for implementing action plans for Brazilian threatened species. FLAVIO RODRIGUES has interests that include the ecology and conservation of the mammals of the Cerrado. ÉRICA CARMO has been studying terrestrial mammals in Brazil for 6 years. 